Program Studi Ilmu Hukum Universitas Putera Batam

\title{
PERBANDINGAN ANTARA PERAN JAKSA DI INDONESIA DENGAN PERAN JAKSA DI DAEARAH ADMINISTRASI KHUSUS MACAO DALAM SISTEM PERADILAN PIDANA
}

\author{
${ }^{1}$ Moh. Andika Surya Lebang, ${ }^{2}$ Rendi Kastra
}

Fakultas Ilmu Sosial dan Humaniora Universitas Putera Batam, Email:andika_lebang@yahoo.com Fakultas Ilmu Sosial dan Humaniora Universitas Putera Batam, Email: rendi.astra@ yahoo.com

\begin{abstract}
Abstrak
Negara Indonesia dan Makau sama-sama menganut sistem hukum kontinental Eropa. Namun demikian, dalam peran kejaksaan dan kejaksaan memiliki perbedaan dan persamaan dalam pelaksanaan tugas, fungsi dan kewajibannya. hal ini dapat dilihat pada pembahasan jurnal ini. dengan adanya kajian terhadap peran kejaksaan tersebut, diharapkan dapat memberikan inspirasi bagi kejaksaan di negara Indonesia sehinnga dapat membenahi kekurangan-kekurangan yang ada. Penelitian ini merupakan penelitian normatif (Normative Approach) yaitu Undang-undang disamping bertumpu pada penelitian normatif, juga ditambah dengan pendekatan teoritis. Selanjutnya dalam menganalisis data digunakan pendekatan kualitatif dan juga didasarkan studi berbasis perpustakaan, yang berarti bahwa bahan yang diperlukan untuk penelitian harus tersedia di perpustakaan, arsip, dan database, undang-undang dan dokumen lainnya.
\end{abstract}

Kata kunci : Jaksa, Indonesia, Makau, Perbandingan.

\section{PENDAHULUAN}

Jaksa dalam bahasa belanda dikenal dengan sebutan aanklager atau officier van justitie, di Indonesia jaksa memiliki peran di dalam persidangan. Peran, yang dimaksudkan adalah jaksa memiliki tugas, fungsi, kewajiban dan serta kewenangan dari sebelum dimulainya persidangan sampai dengan dijatuhkannya putusan oleh hakim yang mana putusan tersebut sudah 
memiliki kekuatan hukum yang tetap atau sudah final and binding dan kemudian diakhiri dengan eksekusi yang dilakukan oleh jaksa eksekutor atau jaksa penuntut umum. Jaksa di Macao juga memiliki peranan namun terdapat beberapa perbadaan dengan peran jaksa di Indonesia dimana hal nanti akan coba dijabarkan didalam pembahasan.

\section{METODE PENELITIAN}

Penelitian ini merupakan penelitian normatif (Normative Approach) yaitu Undang-undang disamping bertumpu pada penelitian normatif, juga ditambah dengan pendekatan teoritis. Selanjutnya dalam menganalisis data digunakan pendekatan kualitatif dan juga didasarkan studi berbasis perpustakaan, yang berarti bahwa bahan yang diperlukan untuk penelitian harus tersedia di perpustakaan, arsip, dan database, undang-undang dan dokumen lainnya (Ibrahim, 2005).

\section{PEMBAHASAN DAN HASIL PENELITIAN}

\section{A. Sistem Peradilan di Indonesia}

Negara Indonesia menganut sistem hukum Civil Law atau juga di kenal dengan nama Eropa Kontinental, dimana dalam hal ini Indonesia manganut sistem hukum Civil law di karenakan pernah di jajah oleh negara Belanda yang menganut sistem hukum Eropa kontinental atau dikenal dengan

Civil law system. Selanjutnya membahas mengenai sistem peradilan pidana 
yang menunjukan mekanisme kerja dalam penanggulangan kejahatan dengan mempergunakan dasar "pendekatan sistem".

Sebagai suatu sistem penegakan hukum, sistem peradilan pidana tidak hanya dimaksudkan untuk memproses penyelesaian kejahatan yang cepat, berbiaya murah dan transparan, akan tetapi juga memberikan perlindungan hak-hak asasi manusia, menghormati asas praduga tak bersalah dari status tersangka sampai dinyatakan bersalah, dan proses penghukuman yang memberikan jaminan keseimbangan antara perlindungan masyarakat dan kepentingan terdakwa.

Sistem Peradilan Pidana yang diserap dalam KUHAP, diberlakukan melalui Undang-Undang Nomor : 8 tahun 1981, menganut sistem Campuran yang meletakan kerangka landasan penyelenggaraan sistem peradilan dengan mengatur hubungan antar subsistem peradilan. Hal demikian juga dapat dilihat dari penyelenggaraan peradilan pidana secara normatif dapat digambarkan sebagai berikut : Tahap Penyelidikan, Tahap Penyidikan, Tahap Penuntutan, Tahap Pemeriksaan disidang peradilan, Tahap upaya hukum, Pelaksanaan Putusan Pengadilan. Dalam sistem peradilan pidana terpadu, Kepolisian, Kejaksaan, Pengadilan dan Lembaga Pemasyarakatan sebagai institusi penegak hukum memiliki hubungan yang erat. Keempat institusi ini seharusnya dapat bekerja sama dan berkoordinasi dengan baik untuk mencapai tujuan dari sistem ini. Mengingat, dalam penegakan hukum faktor penghambat sangat banyak, termasuk faktor-faktor sosial, ekonomi dan sebagainya, tetapi 
justru faktor terpenting penghambat penegakan hukum itu ada di dalam sistem hukum itu sendiri.

\section{B. Sistem Peradilan di Macao}

Republik Rakyat Tiongkok menerapkan asas "satu negara dua sistem". Setelah di Portugis mengembalikan ke RR Tiongkok pada tahun 1999, Macao Special Administrative Region yang disingkat dengan sebutan Macao tetap memiliki hukum sendiri dan tidak mengikuti sistem hukum di RR Tiongkok. Dalam sistem peradilannya Macao juga berdiri sendiri dan tidak tergantung pada sistem peradilan RR Tiongkok.

Sistem peradilan Macao berakar pada sistem peradilan Portugal (termasuk negara Spanyol, Belgia dan Belanda, yang mana kesemuannya berakar pada sistem peradilan Prancis), yaitu peradilan yang bertipe inkuisitor atau non adversarial kejaksaan dan pengadilan berada dalam satu sistem kemagistratan (magistrac), yang artinya kemagistratan terdiri dari magistratan pengadilan dan magistratan kejaksaan, sehingga hakim dan jaksa baik dalam persyaratan pengangkatannya, pemeberhentian, penjatuhan sanksi disiplin, sistem pelatihan, sistem penggajiannya kekebalannya dan lain-lain nya tidak berbeda namun yang berbeda, hakim tidak dapat dimutasi tanpa persetujuannya dan hakim memiliki kebebasan individual yang artinya hakim tidak dapat diperintah oleh siapapun termasuk atasannya sendiri.Sedangkan jaksa dapat dimutasikan ke mana saja, tunduk pada hierarki dan dapat di perintah oleh atasannya. 
C. Kedudukan jaksa di Indonesia

Jaksa menurut Pasal 1 ayat (1) Undang-Undang Nomor 16 Tahun 2004 tentang Kejaksaan Republik Indonesia merupakan "Pejabat fungsional yang diberi wewenang oleh undang-undang untuk bertindak sebagai penuntut umum dan pelaksana putusan pengadilan yang telah memperoleh kekuatan hukum tetap, serta wewenang lain berdasarkan undang-undang”

Selanjutnya,seperti dalam pasal 30 ayat (1) sampai ayat (3) Undang-Undang No.16 Tahun 2004 Tentang kejaksaan menyebutkan :

1) Dibidang pidana, kejaksaan mempunyai tugas dan wewenang :

a) Melakukan penuntutan;

b) Melaksanakan penetapan hakim dan putusan pengadilan yang telah memperoleh kekuatan hukum tetap;

c) Melakukan pengawasan terhadap pelaksanaan putusan pidana bersyarat, putusan pidana pengawasan, dan keputusan lepas bersyarat;

d) Melakukan penyelidikan terhadap tindak pidana tertentu berdasarkan undang-undang;

e) Melengkapi berkas perkara tertentu dan untuk itu dapat melakukan pemeriksaan tambahan sebelum dilimpahkan ke pengadilan yang dalam pelaksanaannya dikoordinasikan dengan penyidik 
2) Di bidang perdata dan tata usaha negara, kejaksaan dengan kuasa khusus dapat bertindak baik di dalam maupun di luar pengadilan untuk dan atas nama negara atau pemerintah.

3) Dalam bidang ketertiban dan ketentraman umum, kejaksaan turut meyelenggarakan kegiatan.

D. Kedudukan jaksa di Macao

Berdasarkan Undang-Undang Dasar Macao, kejaksaan dan pengadilan Macao merupakan lembaga peradilan (judicial organ), maka dari itu kejaksaan macao bukan lembaga pemerintahan (administrative organ). Di negara-negara yang memiliki kejaksaan seperti Macao, kedudukan kejaksaan merupakan lembaga peradilan yang menerapkan teori lembaga peradilan (judicial organ theory), sehingga kedudukan hakim dan jaksa berstatus sejajar (paralel status).

Akan tetapi tidak dapat dipungkiri, bahwa kejaksaan Macao sedikit menganut dua sifat kedudukan jaksa (double nature of the prosecutors) dalam sistem peradilan pidana, yaitu sebagai:

1) Jembatan antara Kepolisian dan Pengadilan

2) Jembatan antara Eksekutif dan Yudikatif

Walau begitu dapat disimpulkan, bahwa kedudukan kejaksaan Macao lebih bertupu pada teori bahwa kejaksaan itu merupakan lembaga peradilan. 
E. Kewenangan (tugas dan fungsi) jaksa di Indonesia

Di dalam Undang-Undang Nomor 16 Tahun 2004 mengatur secara tegas bahwa Kejaksaan memiliki kemerdekaan dan kemandirian dalam melakukan kekuasaan Negara dalam bidang penuntutan. Kedudukan Kejaksaan sebagai suatu lembaga pemerintahan yang melakukan kekusaan negara di bidang penuntutan, bila dilihat dari sudut kedudukan mengandung makna bahwa Kejaksaan merupakan suatu lembaga yang berada di bawah kekuasaan eksekutif. Sementara itu, bila dilihat dari sisi kewenangan kejaksaan dalam melakukan penuntutan berarti Kejaksaan menjalankan kekuasaan yudikatif. Sehubungan dengan makna kekuasaan Kejaksaan dalam melakukan kekuasaan negara di bidang penuntutan secara merdeka

Kedudukan Kejaksaan dalam peradilan pidana bersifat menentukan karena merupakan jembatan yang menghubungkan tahap penyidikan dengan tahap pemeriksaan di sidang pengadilan. Berdasarkan doktrin hukum yang berlaku suatu asas bahwa Penuntut Umum mempunyai monopoli penuntutan, artinya setiap orang baru bisa diadili jika ada tuntutan pidana dari Penuntut Umum, yaitu lembaga kejaksaan karena hanya Penuntut Umum yang berwenang mengajukan seseorang tersangka pelaku tindak pidana ke muka sidang pengadilan.

Pada tahun 2004 dengan keluarnya Undang-undang Nomor 16 Tahun 2004, kedudukan jaksa semakin mempertegas posisi Jaksa sebagai pejabat fungsional yang diberi wewenang oleh Undang-undang untuk 
bertindak sebagai Penuntut Umum dan Pelaksana Putusan Pengadilan yang telah memperoleh kekuatan hukum tetap dan wewenang lain berdasarkan Undang-undang. Dengan demikian pengertian 'Jaksa' pada Undang-Undang No 16 Tahun 2004 lebih luas dari pada pasal 1 butir 6 huruf a KUHAP menyebutkandua kewenangan jaksa yakni :

- Sebagai penuntut umum, dan

- Sebagai eksekutor.

Sedang penuntut umum berwenang untuk :

- Melakukan penuntutan.

- Melaksanakan penetapan hakim.

F. Kewenangan (tugas dan fungsi) jaksa di Macao

Kejaksaan Macao dipimpin oleh Jaksa Agung (Prosecutor General) wewenang utamanya di bidang peradilan pidana, tetapi meliputi juga bidang perdata (termasuk hukum keluarga dan ketenaga kerjaan). Kejaksaan adalah satu-satunya lembaga yang memiliki kewenangan melakukan intervensi secara penuh dalam penegakan hukum dan proses pidana.maka dari itu, di bidang peradilan pidana kejaksaan macao berwenang:

1) Menerima tuduhan (denounce) dan aduan (complaint).

2) Melakukan penyidikan (investigation)

3) Melakukan penuntutan (prosecution) 
4) Melakukan banding (appeal), bahkan kalau perlu demi kepentingan terdakwa.

5) Melakukan eksekusi dan melakukan tindakan-tindakan pengamanan (security measures).

Di Macao, pemerikasaan di sidang pengadilan bersistem inquisitoir dan jaksa Macao bukan merupakan pihak dalam perkara pidana. Sedangkan dalam sistem adversary (sistem peradilan pidana di negera-negara bersistem hukum inggris atau common law system), jaksa merupakan pihak dalam perkara pidana, yaitu pihak yang melawan pihak terdakwa.

G. Kekuasaan Penyedikan jaksa di Indonesia

Proses peradilan pidana melalui berbagai tahapan yang masingmasing tahapan diwadahi oleh institusi dengan struktur dan kewenangan sendiri-sendiri. Dengan melalui berbagai institusi, maka proses peradilan pidana dimulai dari institusi Kepolisian, diteruskan ke Institusi Kejaksaan, sampai ke Institusi Pengadilan dan berakhir pada Institusi Lembaga Pemasyarakatan. Masing-masing institusi ini bertanggung jawab dan bekerja sesuai dengan tugas kewajibannya

Berdasarkan peraturan perundang-undangan yang berlaku dapat disimpulkan bahwa proses pemeriksaan perkara oleh kejaksaan meliputi: Tahap Penyidikan Pengertian penyidikan diatur dalam Kitab Undang-undang 
Hukum Acara Pidana yang terdapat Pada Pasal 1 butir I yang berbunyi sebagai berikut:

Penyidik adalah Pejabat Polisi Negara Republik Indonesia Atau Pejabat Pegawai Negari Sipil tertentun yang diberi wewenang khusus oleh undang-undang untuk melakukan penyidikan. Dari pengertian penyidik diatas, dalam penjelasan undang-undang disimpulkan mengenai pajabat yang berwenang untuk melakukan penyidikan yaitu: Pejabat Polisi Negara Republik Indonesia (POLRI); dan Pejabat PegawaiNegari Sipil yang diberi wewenang khusus oleh Undang-undang untuk melakukan penyidikan.

Tujuan utama penyidikan adalah untuk mencari serta mengumpulkan bukti yang dengan bukti dapat membuat terang suatu tindak pidana yang terjadi dan guna menemukan tersangkanya. Dalam hal penyidik telah selesai melakukan penyidikan, penyidik wajib segara menyerahkan berkas perkara tersebut kepada penutut umum. Dan dalam hal penutut umum berpendapat bahwa hasil penyidikan tersebut kurang lengkap. Penutut umum segera mengembalikan berkas perkara tersebut kepada penyidik disertai petunjuk untuk dilengkapi. Apabila pada saat penyidik menyerahkan hasil penyidikan, dalam waktu 14 Hari penutut umum tidak mengembalikan berkas tersebut, maka penyidikan dianggap selesai.

H. Kekuasaan Penyidikan jaksa di Macao

Kekuasaan melakukan penyidikan merupakan kekuasaan sepenuhnya (exclusive power) kejaksaan Macao. Akan tetapi, sekalipun 
memiliki kekuasaan penyidikan sepenuhnya, kejaksaan Macao merasa tidak sepantasnya melakukan penyidikan secara langsung. Dalam kesehariannya, kekuasaan tersebut didelegasikan kepada kepolisian Macao, sehingga kejaksaan Macao tidak pernah melibatkan secera teknis dalam penyelidikan yang dilakukan oleh poliso. Walaupun demikian, kekuasaan penyidikan yang diberikan sepenuhnya oleh undang-undang kepada jaksa Macao yang tidak memihak (impatrial) dan independen, merupakan jaminan perlindungan bagi para warga Macao.

I. Kekuasaan Penuntutan jaksa di Indonesia jaksa yang menangani perkara dalam tahap penuntutan disebut 'Penuntut Umum'. Penuntut umumlah yang dapat melaksanakan penetapan hakim. Dengan demikian, jaksa lain (yang bukan penuntut umum) tidak dapat melaksanakan penetapan hakim tetapi penuntut umum, dapat melakukan eksekusi karena dia adalah jaksa ( bukan sebagai penuntut umum).

Penuntutan suatu perkara dapat dilakukan dengan berbagai cara. Cara ini tergantung berat ringannya suatu perkara yang terjadi jika suatu perkara itu termasuk perkara biasa yang ancaman pidananya diatas satu tahun, maka penuntutan dapat dilakukan dengan cara biasa. Penuntutan perkara dengan cara biasa ditandai dengan adanya berkas perkara yang lengkap dan rumit, yang memuat berbagai berita acara yang telah disusun oleh penyidik. Ciri utama dari penuntutan ini, yakni selalu disertai dengan surat dakwaan 
yang disusun secara cermat dan lengkap oleh jaksa penuntut umum yang menyerahkan sendiri berkas perkara tersebut dan harus hadir pula di persidangan pengadilan.

Selain penuntutan dengan cara biasa tersebut, penuntutan dapat pula dilakukan dengan cara singkat. Penuntutan ini dilakukan jika perkaranya ancaman pidananya lebih ringan yakni tidak lebih dari 1 tahun penjara. Berkas perkaranya biasanya tidak rumit sekalipun demikian jaksa penuntut umum tetap membuat dan mengajukan surat dakwaan yang disusun secara sederhana. Penuntutan jenis ini, penuntut umum langsung mengantarkan berkas perkara ke pengadilan yang kemudian didaftarkan dalam buku register oleh panitera pengadilan.

\section{J. Kekuasaan Penuntutan jaksa di Macao}

Di samping kekuasaan penyidikan sepenuhnya, kejaksaan Macao diberi kekuasaan sepenuhnya untuk melakukan penuntutan. Menuntut adalah menetapkan berkas perkara yang diterimanya untuk dijadikan kasus pidana. Setelah itu jaksa Macao akan menganalisis dan menetapkan apakah kasus yang bersangkutan diajukan ke pengadilan atau tidak. Karena kejaksaan Macao menganut asas legalitas, bukan asas oportunitas, maka selama buktibuktinya cukup dan sepanjang kejaksaan berwenang (legitimacy), kasus tersebut akan diajukan ke pengadilan.

Kejaksaan Macao dalam melakukan penuntutan mempertimbangkan dua hal yaitu: 
1) Apakah, pembuktian untuk kasus yang dihadapi cukup (sufficient evidence) atau tidak.

2) Apakah, untuk kasus tersebut kejaksaan berwenang (legitimacy) menuntutnya atau tidak.

Jaksa Macao tidak memiliki kekuasaan untuk melakukan diskresi penuntutan seperti yang diatur dalam KUHAP Macao tahun 1997, jaksa Macao boleh mengusulkan kepada pengadilan, bahwa untuk perkara-perkara tertentu, diberikan penangguhan penuntutan (suspension of proceeding) dan penuntutan tanpa penjatuhan pidana (filling in case of exemption of punishment). Dari hal ini dapat disimpulkan bahwa jaksa Macao memiliki kebebasan untuk menuntut perkara dalam hal pembuktiannya cukup memadai.

\section{PERBANDINGAN PERAN JAKSA DI INDONESIA DAN PERAN}

JAKSA DI MACAO

Perbedaan Jaksa Indonesia dan Macao

\begin{tabular}{cc}
\hline Indonesia & Macao \\
\hline Lembaga pemerintah & Lembaga peradilan \\
\hline
\end{tabular}

\begin{tabular}{|cc|}
\hline Memiliki beberapa asas-asas & Terfokus pada asas legalitas saja \\
\hline Tidak memiliki kewenangan dalam & Memiliki kewenangan melakukan \\
melakukan penyidikan & penyidikan
\end{tabular}


Program Studi Ilmu Hukum Universitas Putera Batam

\author{
Ruang lingkup penuntutan terdiri Ruang lingkup penuntutan hanya \\ dari Pidana, Perdata dan Tata dalam kasus Pidana dan Perdata. \\ Usaha Negara. \\ Tidak bersifat double nature of the Bersifat double nature of the \\ prosecutors prosecutors.
}

\title{
Persamaan jaksa di Indonesia dan jaksa di Macao
}

Peran jaksa Indonesia dan Macao dalam agenda persidangan peradilan pidana sama.

Jaksa Indonesia dan Macao sama-sama tidak berwenang untuk melakukan diskresi.

Dalam tahap Penyidikan jaksa menyerahkan kepada pihak Kepolisian Sama-sama menganut asas legalitas

\section{MANFAAT DARI PERBANDINGAN UNTUK JAKSA DI INDONESIA}

Manfaat dari perbandingan ini adalah tambahan ilmu pengetahuan terhadap lembaga kejaksaan dalam membenahi kekurangan yang ada dan juga sebagai tolak ukur para jaksa untuk selalu meningkatkan kinerja dalam mengemban tugas-tugasnya. 
Program Studi Ilmu Hukum Universitas Putera Batam

\section{PENUTUP}

\subsection{Simpulan}

Berdasarkan pembahasan diatas maka dapat disimpulkan :

1) Jaksa di Indonesia dan jaksa di Macao memili persamaan dan perbedaan peran dalam mengemban tugasnya.

2) Kedua negara sama-sama menganut sistem hukum Eropa Kontinental atau Civil Law Sytem, namun dalam sistem peradilan nya terkhusus peran jaksa memiliki perbedaan.

\subsection{Saran}

Dengan adanya pengkajian terhadap perbadingan peran jaksa di Indonesia dan peran jaksa di Macao, dapat memberikan inspirasi kepada jaksa indonesia untuk membenahi kekurangan yang ada, sehingga dapat meningkat kualitas kinerja para jaksa dalam melaksanakan tugas-tugasnya.

\section{DAFTAR PUSTAKA}

\section{Buku}

Peran Jaksa dalam sistem peradilan pidana di kawasan Asia Pasifik, RM Surchman dan Jan S. Maringka, penerbit: SINAR GRAFIKA..

\section{Undang-Undang}

Undang-Undang Nomor 16 Tahun 2004 tentang Kejaksaan Republik Indonesia.

Kitab Undang-Undang Hukum Pidana (Kuhp). 